\title{
The Role Of Character In The Hiring Process: A Pilot Study Survey Of College Seniors' Potential Employers
}

\author{
Michael Firmin, Cedarville University, USA \\ Elizabeth Proemmel, University of Utah, USA \\ Sarah McDivitt, Cedarville University, USA \\ Jennifer Evens, University of Georgia, USA \\ Lew Gibbs, Cedarville University, USA
}

\begin{abstract}
We surveyed 31 prospective employers (65\% response rate) regarding their views on character as part of the employment selection process. The results showed character qualities superordinate, relative to skills that prospective employees bring to potential jobs. We discuss survey results in light of business educators' responsibility for helping students to internalize ethical decisionmaking. Although the results show employers making few company changes due to the media's attention on corporate scandals, respondents express that the pool of applicants with strong character is shrinking. They expect that character training will occur prior to employment in a variety of milieu-including higher education.
\end{abstract}

Keywords: character, employment selection, business education

\section{INTRODUCTION}

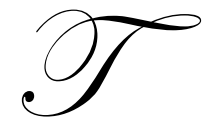

he construct of character in the business world has received particular attention in the media during the last decade, particularly with the string of corporate scandals occurring in the last few years. Lomax (2003) argues that business impropriety has been with the United States since its inception as a country, but the magnitude and scope of the more recent problems dwarf those of previous generations. Integrity (Petrick \& Scherer, 2003) and social responsibility (Carson, 2003), cornerstones of business ethical practice, are particularly highlighted in the commercial scandals of recent times. Sridharan, Dickes, and Caines (2002) stress that instructors of business courses need to capitalize on these events and use them as teaching opportunities for student learning. If this is not done, then history is bound to repeat itself as current students enter their business careers. Unfortunately, without deliberate and attentive learning — vicarious shame has a relatively short shelf-life.

While the U.S. media has highlighted American corporations, business ethical problems are universal. The literature indicates that difficulties have been experienced abroad with Enron-type issues occurring across multiple business milieu. The heightened need for international attention to corporate ethics has been sounded in Great Britain (Brown, Deakin, Hudson, \& Pratten, 2001; Sullivan, 2003), Spain (Salgado, 2003), Finland (Suutari, 2003; Vitterso, et al, 2003), Russia (Lindquist, 2002), and the Middle East and Africa (Abbott, 2002), to name a few. In short, the need for the apt application of business ethics is not local, but rather world-wide, particularly with the recent propagation of international business.

Assuming the need for developing business ethics, where do entry-level workers learn the requisite moral codes? Some have pointed to the salience of spiritual development or religious values as a mooring for ethical decision-making (Wallace \& Bergeman, 2002; Warren, 1998; Wilsensky \& Hansen, 2001). McKay (2003) argues that high school is the place where students need to develop ethical understanding. Both Nielsen (2001) and Doris (2002) advocate that ethical instruction must contain both intellectual understanding and affective concern in the decision-making process. Without both of these elements, understanding will occur apart from motivation, leading 
to eventual unethical behavior. Regardless of what ethical understanding business students bring with them to the college classroom, instructors have an obligation to do their utmost at developing students ethically and shaping their paradigms toward ethical business practice.

It is difficult to research the topic of business ethics apart from conceptions of morality (Schumann, 2001). There is no universally agreed-upon definition for the construct of business ethics, although Finegan (1994) makes a case for personal values as a basis for ethical development. Some frame ethics in terms of rightness or wrongness (Gibson, 2000) and others frame the construct from the standpoint of rules that one must follow in order to avoid consequences (O’Neil, 1981). In the present post-modern era and society, it is difficult for university professors to teach an absolute moral code in which all students, by faith, agree and to which they will commit themselves. Consequently, morality, in business ethics contexts, tends to be understood in terms of societal good as defined by legislative and statutory law (Vidu, 1999).

Since business ethics is such a broad domain, the present study focuses on a relatively narrow band within its context for research purposes. Namely, we give attention to the construct of character in the workplace. Experts consistently identify it as a salient quality for ethical decision-making in business contexts (Anfuso, 1995; Kaplan, Drath, \& Kofodimos, 1991). However, there is no clearer consensus in defining character than there is in defining ethics. Lisoski (2003) suggests an abstract definition involving courage with a conscience, whereas Levinson (1997) suggests consistency of individual behavior is the best means of operationally describing the construct. An important distinction, from our perspectives, is to demarcate character from personality traits. Hogan (1996) notes that sometimes when employers indicate a desire for character in their workers, what they really want are personality characteristics such as how workers interact with people, emotional stability, and organizational skills. Maynard (1994) suggests that the sum total of decisions made by employees, including those made under pressure, is the measure of their character.

Obviously, character is an immense domain for study. Consequently, we have chosen to focus the present study on one domain of character, relating it to the hiring process. In particular, we are interested in how prospective employers view this construct when they enter a college campus and recruit seniors for entry-level positions. Gilliland (1993) indicates that character and ethics are indeed connected in the hiring process relative to requisite qualities for employment consideration. Legal issues, however, must be considered when decisions are made during screening, should lack of character be cited as a reason for rejection (White, 1995). We already noted that character is a highly ambiguous concept, which opens a company up to potential legal challenges anytime hiring criteria are unclear.

Bartram's (2001) research suggests that employee characteristics, such as honesty and integrity, are valued more highly by small businesses than by larger ones when compared with job skills that prospective employees bring to the work setting. However, Brown, Jones, Terris, and Steffy (1987) indicate that large national chains highly value employee integrity since they tend to suffer enormous losses when workers purloin. That is, one worker's petty theft does not significantly effect profits, but when this factor is multiplied across hundreds of stores nationwide, costs escalate quickly. And finally, Colarelli (1996) indicates that although businesses generally agree that character is an important component regarding the hiring process, in the past 80 years relatively little research has been conducted in this area.

\section{METHOD}

Our study involved survey research with the purpose of better understanding how companies view the construct of character relative to the hiring process. The institution based upon which the data were drawn was a private, selective, comprehensive university located in Midwestern America. It enrolls 3000 students and the Career Services department possesses a fluid annual database of around 1000 prospective employers. These are companies and corporations where university students have found employment and internships within the past decade. Fortyeight (48) companies were selected for the survey, based on the companies' past records of hiring students with majors in business, engineering, communications, education, health care, science/math, and government-related occupations. These majors represented some of the most widely-utilized placements in the institution's Career 
Services department at the time of data collection. The companies participated in a previous unpublished survey and were judged as likely respondents for the present study.

Anonymity was assured to each of the companies participating in the research. A wide cross-section of small, medium, and large corporations were represented in the sample. Persons directly responsible for hiring new employees were asked to complete the survey in each company. No incentives were offered subjects, other than the obvious good will and continued relationship with the university's Career Services department. We asked thirty questions on the survey that queried the company's perspective regarding character in the hiring process. The surveys were returned to us via a paid self-stamped addressed envelope or via fax. Thirty one (31) companies replied, for a response rate of $64.6 \%$.

\section{RESULTS}

\section{Ordinal Character Characteristics}

We provided the participants with a list of ten qualities indicated in Job Outlook as being important to prospective employers. They were presented in alphabetical order: analytical skills, communication skills, computer skills, flexibility/adaptability, honesty/integrity, interpersonal skills, motivation/initiative, self-confidence, strong work ethic, and teamwork skills. The participants were asked to rank the items according to the importance the organization places on these personal qualities in job applications.

Throughout this paper, percentages are rounded to the nearest whole number for clarity of read. Results showed $61 \%$ of the respondents to rank honesty/integrity as number one and an additional $42 \%$ ranked work ethic as number two. Additionally, $71 \%$ of all respondents ranked honesty/integrity as either their first or second priority. Fifty-two percent $(52 \%)$ ranked strong work ethic as first or second. From this data we deduced that companies report placing a premium on character qualities over skill variables when considering new hires. That is, skill items were selected as being of lesser importance when compared to character-related items (honesty/integrity and strong work ethic). Interestingly, $26 \%$ of the respondents selected motivation/initiative as their first or second rank. Compared with the other skill-related options provided, this finding lends further support to the character emphasis.

Participants also were asked to rank, when considering candidates for their organizations, three sets of preferences. Following were the results. Forty-five percent (45\%) indicated employees who make choices based on outcome, striving for the best results for the most people; Thirty-one percent (31\%) indicated employees who make choices based on obligation or duty (i.e., family, the organization, society, etc.) regardless of personal attitude or beliefs; and Twenty-four percent (24\%) indicated employees who make choices based on deeply held, core convictions, personal values and beliefs. In sum, respondents seemed to value ethical moorings based on what was best for the company's interests, rather than personal values or ethics related to responsibility. This obviously has potential implications for how business educators might choose to approach attempts at helping students to internalize ethical decision-making and values clarifications in preparation for post-baccalaureate jobs.

\section{Integrity Testing And Behavioral Interviews}

Of the companies responding to our survey, $20 \%$ utilized some type of honesty/integrity testing. All of those using such assessments indicated that it provides bearing on the ultimate decision of hiring. Half of those using such instruments indicated overt methods and half said that they used more tacit measures (unspecified on the survey). All of the companies indicating the use of some form of honesty/integrity testing included measures of human personality. Fifty-eight percent (58\%) of respondents indicated using documented behavioral interviews, and of those utilizing them, $89 \%$ reported that they significantly effect selection decisions and $45 \%$ indicated their belief that they had some-to-great effect in determining job applicant future behavior.

In sum, relatively few companies in our sample depend on formalized testing in order to screen for character in applicants. Traditional pencil-and-paper measures, such as personality testing, evidently sill enjoy popularity. Documented behavioral interviewing shows relatively strong support as a part of character assessment, although only about half of those using the method evidently have sound confidence in the method. 


\section{References}

Sixty-five percent $(65 \%)$ of respondents to our survey have forms that they ask applicants to have references complete. All of those using such forms agree that they have some-to-great effect in determining job applicant behavior. Half of those using the forms believe that they have some-to-great effect in determining job applicant behavior. Seventy-seven percent $(77 \%)$ of respondents indicate having conversations with references provided by job applicants. Of those, $92 \%$ indicate that these conversations significantly effect selection decisions and $65 \%$ believe that the conversations have some-to-great effect in determining the applicant's future behavior. Interestingly, $77 \%$ of the respondents indicate using other methods, besides references and testing, for assessing character (such as background checks).

Providing references seems standard practice for job hiring. A relatively high percentage appear to prefer some type of personal contact with the references. Obviously job applicants tend to identify their most amiable people as references rather than people who would be likely to provide hostile feedback. However, about a third of the employers are somewhat wary regarding the effectiveness of references for character assessment. It may be that a positive reference provides only an indication to proceed further, rather than an indicator for potential hire. A negative reference, on the other hand, may carry much more significant potential than a positive one, particularly if the prospective employer conducts personal contact with that reference.

\section{Pool Of Applicants}

Sixty-one percent $(61 \%)$ of the respondents believe that the pool of applicants with strong character traits is shrinking. When queried about where character should be taught, respondents provided the following responses to a list of preferences provided to them: Home (97\%), place of worship (97\%), school (90\%), institution of higher learning (77\%), business place (52\%), and governmental initiatives (16\%). There is a clear proximodistal tendency in the findings of our survey relative to where character should be taught. That is, companies believe that character development should begin with close connections, such as the family unit, and move outward to more distant connections, such as the workplace or government. We may infer, therefore, that businesses desire for workers to have been pre-shaped relative to character development, long before they arrive for their initial day of employment. Of particular interest to business educators is that over three quarters of the respondents indicated that colleges share a significant responsibility for providing character development in potential job applicants.

\section{Character And The Final Work Product}

All respondents indicated that a lack of character has a negative impact on the bottom-line of work with an almost equal number (97\%) saying that good character is a parallel positive influence. Ninety-four percent (94\%) believe that a character lack in employees negatively influences organizational culture to some, or, to a great effect. Conversely, exercising strong character traits is believed to have has an equally opposite effect.

\section{Changes Since National Corporate Scandals}

Sixty-five percent (65\%) of those responding to our survey indicated having a formal, written "statement of ethics" or vision statement guiding ethical employee behavior. Only 7\% of the businesses have made explicit changes in their company policies concerning ethical employee behavior since the national scandals grabbed media attention. Also, only $10 \%$ believe that with the recent scandals, their own employee selection was affected to either some or a great effect.

Of all the findings in our survey, the lack of reported change in behavior by companies is perhaps one of the most interesting. These businesses may feel that what they have in place is adequate or perhaps that they are somehow insulated from the weak links that brought down Enron, Arthur Anderson, Martha Stewart, and others. A review of Ken Lay's (1991) Enron story makes no mention of ethics or character in the workplace as a potential contributor to the corporation's success. In any event, the companies in the present study feel relatively confident regarding their own practices - despite the monthly reports of new corporations facing ethical violations in the media. 


\section{SUMMARY}

Character is identified to be an important characteristic of potential employers, according to the data collected in the present study. It is believed to significantly effect the bottom-line of work productivity. Traditional virtues such as honesty/integrity and a strong work ethic are valued in the work place, above job skills relative to ordinal options. Relatively few companies in our sample use formal integrity testing, with more relying on documented behavioral interviews. Personal references are still used, although with about a third of employers viewing them with some apparent skepticism, and they prefer personal conversations over written forms for validity.

Almost two thirds of our sample believe that the pool of applicants exhibiting strong character traits is shrinking. They want to hire employees who have learned character at home, religious affiliations, school, and college-prior to arriving at the workplace. About two-thirds of companies have a written company policy regarding ethical employee behavior and less than $10 \%$ of businesses report making significant changes in company policy as a result of the media's promotion of corporate scandals.

\section{DISCUSSION}

Among the numerous findings, four particular connections among the data seem particular salient. First, employers describe a shrinking valuable commodity. Overall, employers indicate valuing character in employees, but also are concerned that they have less apt individuals from which to choose as they once did. This finding is consistent with previous research, suggesting that nationally - employees share this over-arching concern (Griffith, Zhang, \& Cavusgil, 2006; Holt, 2006). Colleges, in particular, from whom employers often depend for newrecruits, have seen this trend for some time (Athanasou \& Olasehinde, 2002). Locating able new recruits who possess the type and degree of character needed for promotion and organizational leadership likely will be a continual challenge for future employers. Generally, survey data sponsored by the Pew Foundation (Kohut, Parker, Keeter, Doherty, \& Domock, 2007) describe the new generation of 18-25 years olds as seeing fewer absolutes in life and as possessing more tolerant and ambiguous views of right and wrong than did individuals in previous generations.

Employers may be particularly challenged in locating new recruits with character as the employers in the present study describe character generally as being shaped prior to the college years. That is, home, religion, preand-secondary school, and other early influences are believed to carry more heavy weight in character formation than does character development in college-and-beyond. While this perspective is consistent with traditional views of moral development (e.g., Kohlberg, 1969; Norman, Richards, \& Bear, 1998), such early shaping behaviors are factors over which prospective employers have relatively little control. Consequently, it makes locating or developing individuals with strong character to be even more challenging (Langlais, 2006). Consistent with Riley (2005), university business-school ethics indoctrination may not be as strong-of-influence in shaping character as is early instillation of moral principles. According to perspectives of the employers in the present survey, what students bring with them to college (ethically) is more cogent than what they learn while they are in college and beyond.

Second, honesty and integrity seem to be cornerstones for describing how character manifests itself in the workplace. Obviously, character is a construct. As such, it can not be handled, touched, or drawn on a sheet of paper. But as with other constructs, reasonable people agree that it exists (Damer, 1987). In the present context, employers operationalize character via how employees display honesty, (truth-telling) and integrity (showing reliability between what one says and what one does). Such outward manifestations seem reasonable outworkings for what traditionally has been discussed in terms of character (Athanasou \& Olasehinde, 2002). Moreover, it also is natural to reason that lack of these two foundational characteristics in leadership could result in company sanctions, penalties, and other detriments in the workplace (Achoido \& O'Donnell, 2005). This point is noted since the survey respondents indicated that behavioral results in the workplace were ranked higher in importance, relative to character development, than were the possession of behavioral convictions.

Third, employers generally describe themselves as placing more trust in their own instincts during the hiring process (relative to character) than they do in more scientific methods. Relatively few employers in the 
present survey indicated using integrity tests-but rather behavioral interviews. Further, rather than depending on reference letters, employers tend to prefer calling the references personally, making connections with them. Significant weight is given to these conversations and two-thirds of the employers believe that how these references describe prospective employees' character will match respective future employee behaviors. These findings are consistent with conclusions by Jones (2007a; 2007b) and Ellsworth (2007) that company leaders often tend to give more attention to affective rather than scientific data input (trusting instincts versus trusting pure objectivity) among a relative wide-spectrum of executive decision-making. In sum, in the present context - employers seem to prefer contact with the people that they will hire and lean on the subjective verification of others to confirm their hiring perspectives.

Fourth, while there is a concern for character on the national business level, this concern does not necessarily filter-down to the concerns of individual employers. For example, $97 \%$ of those surveyed in our study believe that character is important to the final outcome of prospective employees and almost two-thirds of prospective employers believe the pool of character-possessing prospects is shrinking. However, only $7 \%$ of the individuals interviewed described their own companies as being vulnerable to this trend. Further, only $10 \%$ said that they have modified their own selection process vis-a-vis the character crisis in national industry. In short, a phenomenon may be occurring whereby employers view others as being more vulnerable than they view themselves. Wargo (2006) suggests that everyone is subject to this type of self-serving bias that somehow we are unique among others who are vulnerable. Obviously, that type of insulation thinking might not be healthy for respective individual employers - and perhaps more personal vigilance might be warranted. "It happens to thembut it would never happen to me" could be a vulnerable mentality against which employers should exercise caution and guard against.

\section{LIMITATIONS AND FUTURE RESEARCH}

All apt researchers acknowledge the limitations of their study and are transparent regarding areas where it lacks generalizability. Our response rate of almost 65\% does not account for 35\% of the companies in the target sample. It is theoretically possible that the most ethical companies responded to our survey or that there are other sample biases which act as moderating variables to the study. In addition, our sample was directed to the businesses that for ten years have been attracted to a relatively small, private, comprehensive university in Midwest USA. There was no attempt to create a true random sample of all American corporations, midsized or small businesses. We believe that the present study serves as an excellent prototype and potential basis for grant funding, for future projects of this type on a much larger scale. And finally, the results from the present research are self-reported and were completed by one individual at each company who was identified as being responsible for hiring new employees. We believe that this study should be followed by a qualitative project, providing in-depth interviews of such employers and enhancing the self-report information with ethnographic data. This would provide more rich descriptions that will elucidate the more general findings that we report in the present survey. Qualitative descriptions also may help to fill-in the present missing gaps that pertain to character's role in the ethical education of business students.

\section{ACKNOWLEDGEMENTS}

We wish to acknowledge our appreciation to Alison Reemtsm and J. Michael Lopez for their contribution to this project, including a pilot project serving as a precursor to the present study.

\section{AUTHOR INFORMATION}

Michael Firmin earned his Ph.D. from Syracuse University. He serves as professor and chair of the psychology department at Cedarville University in Cedarville, $\mathrm{OH}$. Firmin has more than 60 peer-reviewed publications and over 100 papers presented at national research conferences. He is a licensed psychologist in the state of Ohio. Firmin serves as editor for the Journal of Ethnographic \& Qualitative Research and directs the national Ethnographic \& Qualitative Research Conference, now in its 21 st annual year. 
Elizabeth Proemmel earned a B.A. in Psychology from Cedarville University in 2004. She currently is a Ph.D. student at the University of Utah. Proemmel has been involved with undergraduate teaching at UH as well as serving in a graduate assistant (GA) capacity. Research experience, including journal publication, has included teaching statistics, career development, teacher's ratings of student behaviors, and character's relationship to the hiring process.

Sarah McDivitt received her B.A. in General Psychology at Cedarville University in 2004. She spent 10 months in Beijing, China teaching English to Chinese students at Renmin University. Having completed her M.A. in General Education at Elmira College in New York (2008), Sarah currently is earning her NYS Teaching Certification in high school English. McDivitt previously has published research involving the role of character in the hiring process.

Jennifer Evens is an Executive Assistant at ghSMART. She is responsible for providing support to two Principals, managing projects, scheduling assessments, invoicing, meeting planning, and travel. Prior to joining ghSMART, Jennifer worked as an Executive Assistant / Project Coordinator, supporting senior leaders in leading companies in organizational consulting.

Jennifer holds an M.Ed. in Human Resources and Organizational Development from the University of Georgia and a B.A. in Psychology from Cedarville University.

Lew Gibbs has served as the Career Services Director at Cedarville University since 1996. He assumed this position following 31 years working in management at IBM. Gibbs has made frequent publication contributions to trade periodicals and newspapers as well as making periodic guest appearances on radio and television programs. $\mathrm{He}$ is an active member in regional and national business organizations and Gibbs currently has plans for coauthoring a book on character-based hiring in corporate America.

\section{REFERENCES}

1. Abbott, J. (2003). Does employee satisfaction matter? A study to determine whether low employee morale affects customer satisfaction and profits in the business-to-business sector. Journal of Communication Management, 7, 333-339.

2. Acohido, B., \& O'Donnell, J. (2005). Extramarital affair topples Boeing CEO. USA Today. March, 8, 2005. B 1-2.

3. Anfuso, D. (1995). Look beyond skills when making hiring decisions. Personnel Journal, 74, 94.

4. Athanasou, J. A., \& Olasehinde, O. (2002). Male and female difference in self-report cheating. Practical Assessment, Research \& Evaluation, 8(5). Retrieved July 24, 2006 from http://PAREonline.net/getvn.asp?v=8\&n=5.

5. $\quad$ Bartram, D., Lindley, P. A., Marshall, L., \& Foster, J. (1995). The recruitment and selection of young people by small businesses. Journal of Occupational and Organizational Psychology, 68, 339-358.

6. Brown, T. S., Jones, J. W., Terris, W., \& Steffy, B. D. (1987). The impact of pre-employment integrity testing on employee turnover and inventory shrinkage losses. Journal of Business \& Psychology, 2, 136149 .

7. Brown, W., Deakin, S., Hudson, M., \& Pratten, C. (2001). The limits of statutory trade union recognition. Industrial Relations Journal, 32, 180-194.

8. Carson, T. L. (2003). Self-interest and business ethics: Lessons of the recent corporate scandals. Journal of Business Ethics, 43, 389-395.

9. Colarelli, S. M. (1996). Establishment and job context influences on the use of hiring practices. Applied Psychology: An International Review, 45, 153-176.

10. Damer, T. E. (1987). Attacking faulty reasoning ( $2^{\text {nd }}$ ed.). Belmont, CA: Wadsworth.

11. Doris, J. M. (2002). Lack of character: Personality and moral behavior. New York: Cambridge University Press.

12. Ellsworth, M. (2007). Charisma or character? Executive Housekeeping Today, 29(1), 2.

13. Finegan, J. (1994). The impact of personal values on judgments of ethical behavior in the workplace. Journal of Business Ethics, 13, 747-756.

14. Gibson, K. (2000). Excuses, excuses: Moral slippage in the workplace. Business Horizons, 43, 65-73. 
15. Gilliland, S. W. (1993). The perceived fairness of selection systems: An organizational justice perspective. Academy of Management Review, 18, 694-734.

16. Griffith, D. A., Zhang, C., \& Cavusgil, S. (2006). Journal of World Business, 41, 356-367.

17. Hogan, J. (1996). Character fitness. Psychology Today, 29, 28.

18. Holt, R. (2006). Principals and practice: Rhetoric and the moral character of managers, Human Relations, $59,1659-1680$.

19. Jones, D. (2007a). Could insecurity be the secret to CEOs' success? USA Today. February 1, 2007. B 1-2.

20. Jones, D. (2007b). It's lonely—and thin skinned—at the top. USA Today. January 16, 2007. B 1-2.

21. Kaplan, R. E., Drath, W. H., \& Kofodimos, J. R. (1991). Beyond ambition: How driven managers can lead better and live better. San Francisco: Jossey-Bass.

22. Kohlberg, L. (1969). Stage and sequence: The cognitive-developmental approach to socialization. In D. Goslin (Ed.), Handbook of socialization theory and research. Chicago: Rand McNally.

23. Kohut, A., Parker, K., Keeter, S., Doherty, C., \& Domock, M. (2007). How young people view their lives, futures and politics: A portrait of "generation next." Washington, D.C.: Pew Research Center for the People \& the Press.

24. Langlais, P. J. (2006). Ethics for the next generation. The Chronicle of Higher Education. January 13, 2006. B11.

25. Lay, Kenneth. (1991). The Enron story. Princeton, NJ: Princeton University Press.

26. Levinson, H. (1997). Organizational character. Consulting Psychology Journal: Practice \& Research, 49, 246-255.

27. Lindquist, G. (2002). Spirits and souls of business. Journal of material Culture, 7, 329-343.

28. Lisoski, E. (2003). Courage, character and conviction-The three "c's" of outstanding supervision. Supervision, 64, 19-21.

29. Lomax, S. (2003). Cooking the books. Business \& Economic Review, 49, 3-9.

30. Maynard, R. (1994). Focusing on a prospect's personality traits. Nation's Business, 82, 14.

31. Nielsen, R. P. (2001). Can ethical character be stimulated and enabled? An action-learning approach to teaching and learning organizational ethics. In J. Dienhart, D. Moberg, et al. (Eds), The next phase of business ethics: Integrating psychology and ethics (vol. 3). Greenwich, CT.: Elsevier Science/JAI Press.

32. Norman, A. D., Richards, H. C., \& Bear, G. G. (1998). Moral reasoning and religious belief: Does content influence structure? Journal of Moral Development, 27, 89-99.

33. O'Neil, R. F. (1981). The artist's perception of the typical businessman: Selfish, greedy, conniving and thoroughly amoral. International Journal of Social Economics, 8, 31-39.

34. Petrick, J. A., \& Scherer, R. F. (2003). The Enron scandal and the neglect of management integrity capacity. Mid-American Journal of Business, 18, 37-49.

35. Riley, N. S. (2005). Higher, higher education. USA Today. June 22, 2005. A 15.

36. Salgado, J. F. (2003). Predicting job performance using FFM and non-FFM personality measures. Journal of Occupational and Organizational Psychology, 76, 323-346.

37. Schumann, P. L. (2001). A moral principles framework for human resource management ethics. Human Resource Management Review, 11, 93-112.

38. Soni, V. (1999). Morality vs. mandate: Affirmative action in employment. Public Personnel Management, 28, 577-595.

39. Sridharan, U. V., Kickes, L., \& Caines, W. R. (2003). The social impact of business failure: Enron. MidAmerican Journal of Business, 17, 11-21.

40. Sullivan, L. (2003). Beyond corporate scandal headlines. Risk Management, 50, 8.

41. Suutari, V. (2003). Global managers: Career orientation, career tracks, life-style implications and career commitment. Journal of Managerial Psychology, 18, 185-207.

42. Vitterso, J., Akselsen, S., Evjemo, B., Julsrud, T. E., Yttri, B., \& Bergvik, S. (2003). Impacts of homebased telework on quality of life for employees and their partners: Quantitative and qualitative results from a European survey. Journal of Happiness Studies, 4, 201-233.

43. Wallace, K. A., \& Bergeman, C. S. (2002). Spirituality and religiosity in a sample of African American elders: A life story approach. Journal of Adult Development, 9, 141-154.

44. Wargo, E. (2006, August). The myth of prodigy and why it matters. Association for Psychological Science Observer, 19(8), 17-20. 
45. Warren, H. A. (1998). The shift from character to personality in mainline Protestant thought. Church History, 67, 537-555.

46. White, R. J. (1995). Hiring employees: Select for character, train for skills. Credit Union Executive, 35, 2225 .

47. Wilensky, A. S., \& Hansen, C. D. (2001). Understanding the work beliefs of nonprofit executives through organizational stories. Human Resource Development Quarterly, 12, 223-239.

48. Williams, D. D., Yanchar, S. C., Jensen, L. C., \& Lewis, C. (2003). Character education in a public high school: A multi-year inquiry into unified studies. Journal of Moral Education, 32, 3-33.

\section{$\underline{\text { NOTES }}$}


NOTES 